\title{
THE NATALICIA: CHRONOLOGY AND CONCORDANCE
}

$\begin{array}{lll}\text { Order in Series } & \text { Year of Performance } & \text { Number in Corpus } \\ \text { First } & \text { January, 395 (Spain) } & \text { Carmen 12 } \\ \text { Second } & \text { January, 396 (Nola) } & \text { Carmen I3 } \\ \text { Third } & \text { January, 397 } & \text { Carmen I4 } \\ \text { Fourth } & \text { January, 398 } & \text { Carmen 15 } \\ \text { Fifth } & \text { January, 399 } & \text { Carmen I6 } \\ \text { Sixth } & \text { January, 400 } & \text { Carmen 18 } \\ \text { Seventh } & \text { January, 401 } & \text { Carmen 23 } \\ \text { Eighth } & \text { January, 402 } & \text { Carmen 26 } \\ \text { Ninth } & \text { January, 403 } & \text { Carmen 27 } \\ \text { Tenth } & \text { January, 404 } & \text { Carmen 28 } \\ \text { Eleventh } & \text { January, 405 } & \text { Carmen 19 } \\ \text { Twelfth } & \text { January, 406 } & \text { Carmen 20 } \\ \text { Thirteenth } & \text { January, 407 } & \text { Carmen 21 } \\ \text { Fourteen } & \text { After 407 } & \text { Carmen 29 }\end{array}$




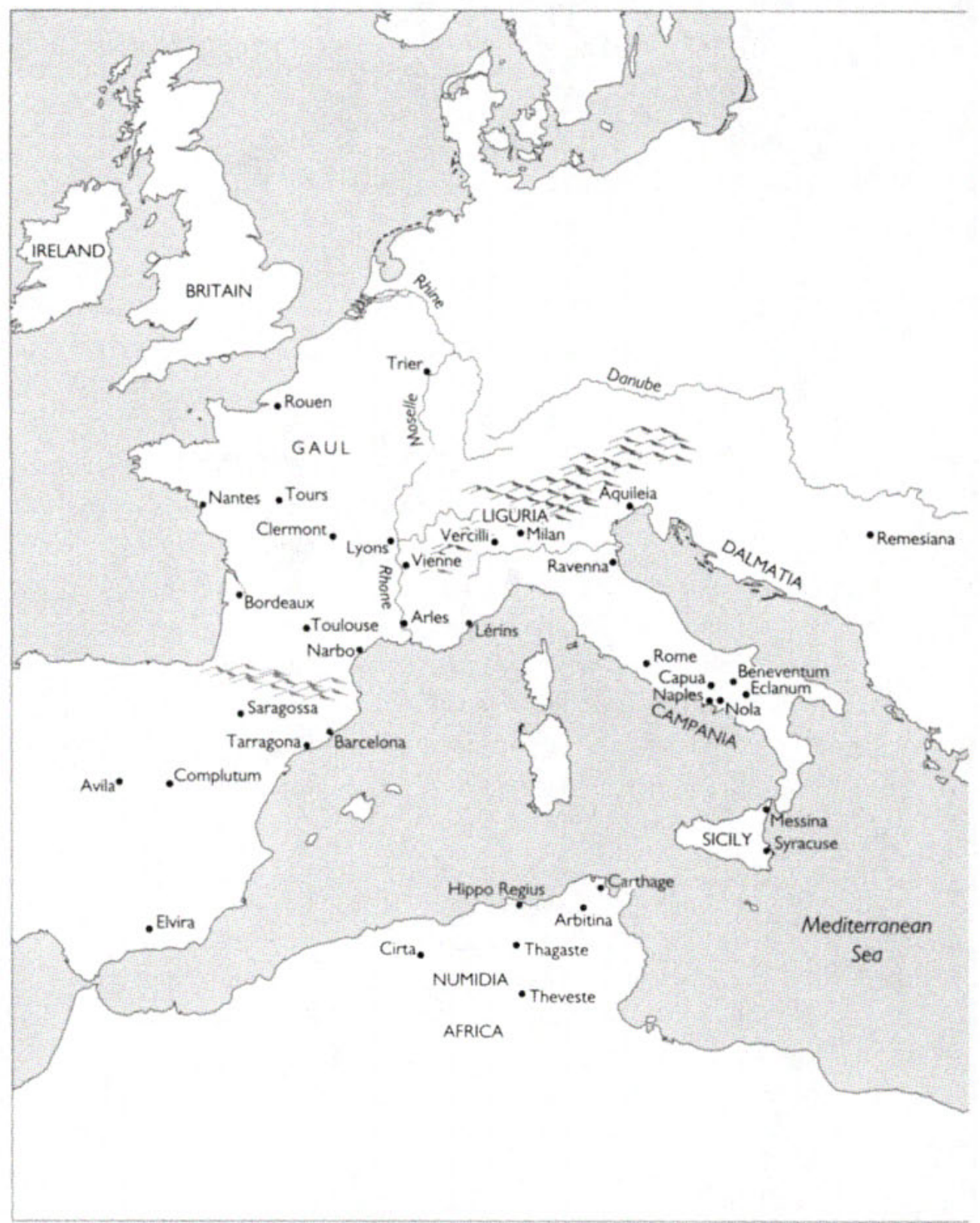

Paulinus's world. Adapted from Brown, The Body and Society. 


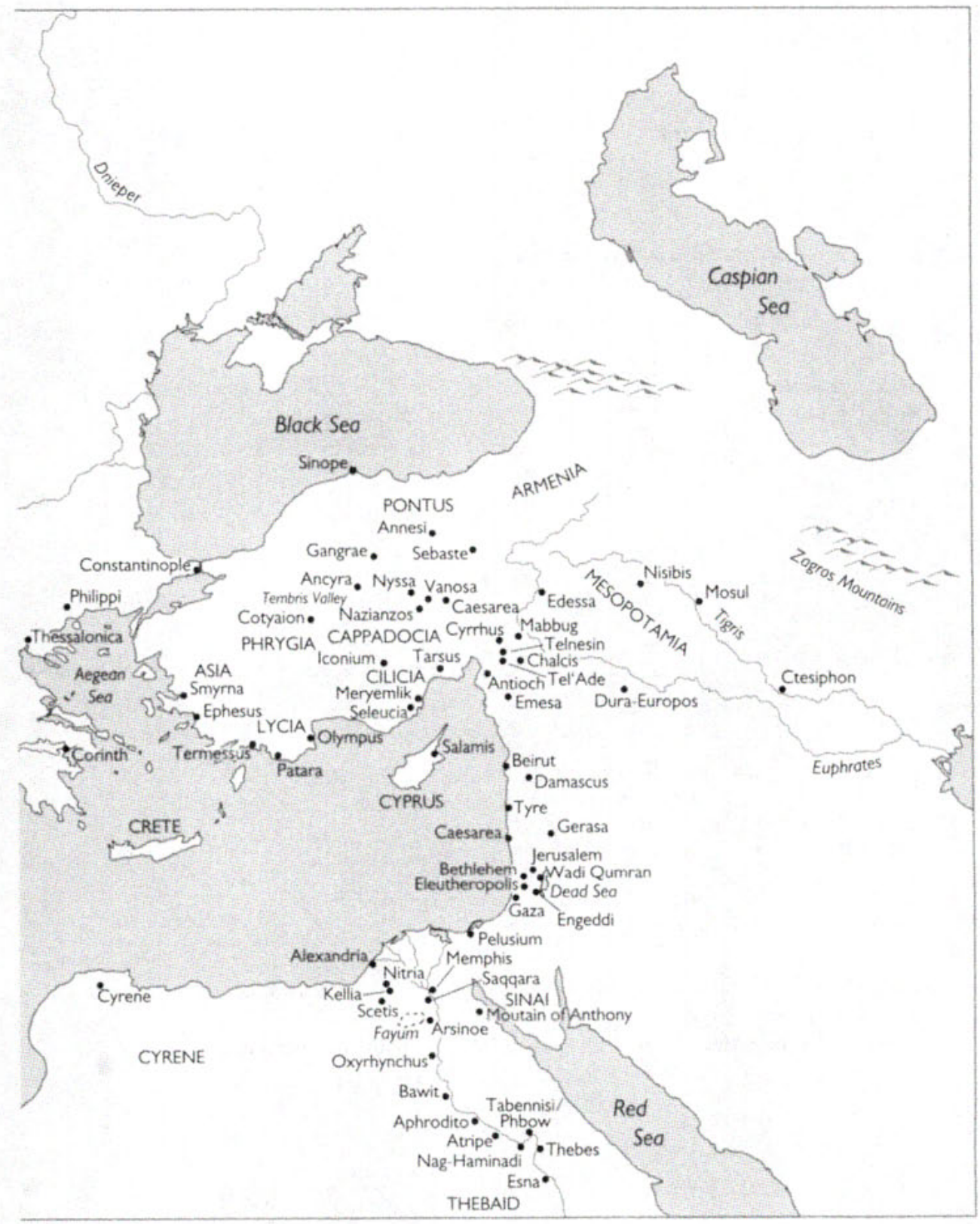




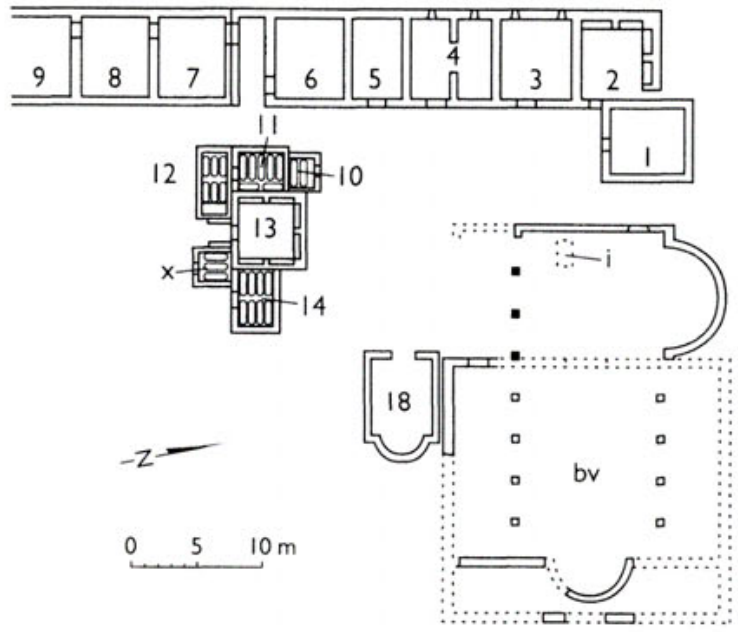

1-9 pagan tombs of the second and third centuries

13 Christian mausoleum of the third century

10-14 Christian mausolea of first half of fourth century

$x \quad$ tombs of first half of fourth century

18 S. Calionio (before the fifth century)

bv the Basilica Vetus (fourth century, before 380-8I)

i tomb of Felix

Figure 1. Plans of the basilica complex at Nola / Cimitile. Courtesy of T. Lehman; adapted from Boreas 13 (1990).

1a. The basilica complex at the time of Paulinus's Campanian governorship (380-8I). 


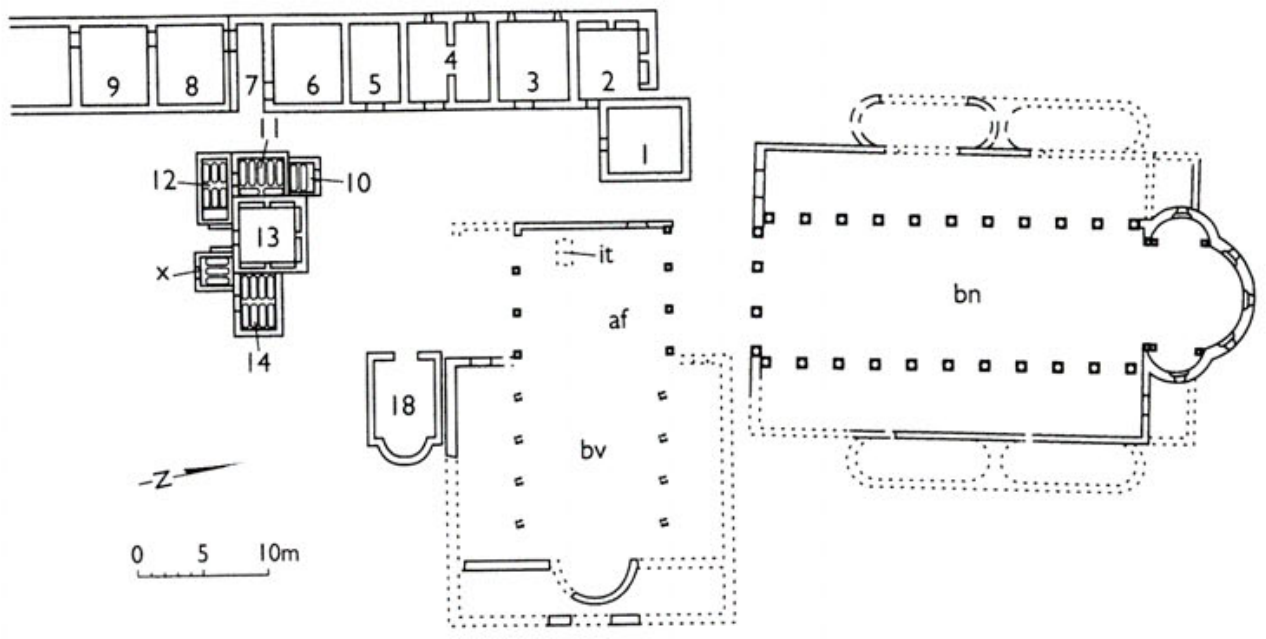

I-9 pagan tombs of the second and third centuries

13 Christian mausoleum of the third century

10-14 Christian mausolea of first half of fourth century

$x \quad$ tombs of first half of fourth century

18 S. Calionio (before the fifth century)

af the "aula" of Felix of late Constantinian era with northern apse removed by Paulinus $\mathrm{ca}$. $40 \mathrm{I}-02$

bn the Basilica Nova built by Paulinus (ca. 401-03)

bv the Basilica Vetus (fourth century, before 380-8I)

it tomb of Felix enclosed by marble screens (ca. 400)

Ib. The basilica complex ca. 403 following Paulinus's construction of the Basilica Nova. 

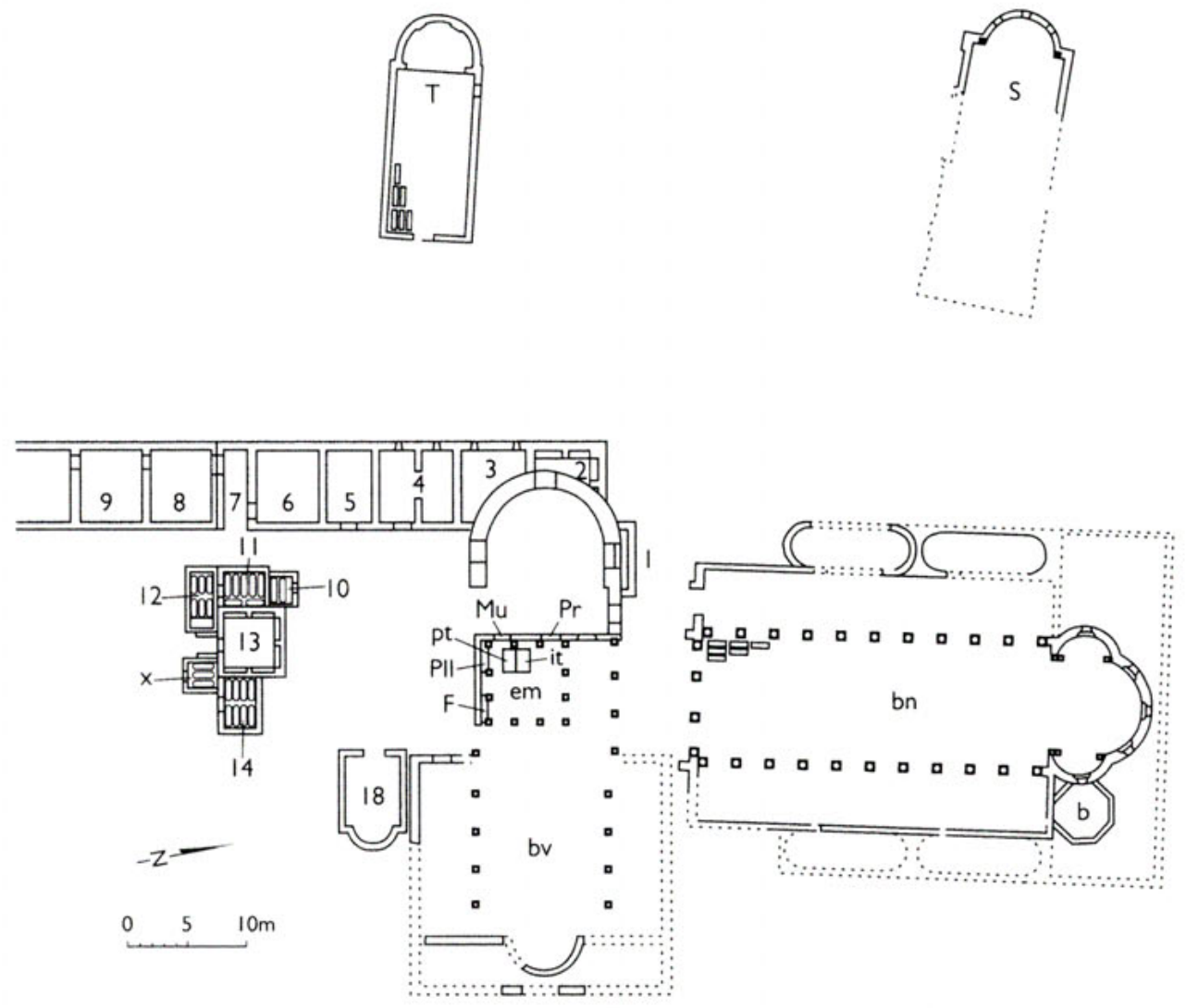

1-9 pagan tombs of the second and third centuries

13 Christian mausoleum of the third century

10-14 Christian mausolea of first half of fourth century

18 S. Calionio (before the fifth century)

21 the great apse (ca. 550?)

b octagonal structure of fifth or sixth century

bn the Basilica Nova built by Paulinus (ca. 401-03)

bv the Basilica Vetus (fourth century, before 380-8I)

em mosaic decorated peristyle (ca. 500)

it tomb of Felix enclosed by marble screens (ca. 400)

pt tomb of Paulinus

F tomb of bishop Felix (d.484)

Mu tomb of bishop Musonius (d. 535)

PII tomb of bishop Paulinus II (d. 442)

Pr tomb of bishop Priscus (d. 523)

S S. Stefano (sixth century and later)

T S. Tommaso (sixth century)

Ic. The basilica complex in the later fifth and sixth centuries. 